\title{
Guest-binding behavior of peptide nanocapsules self-assembled from viral peptide fragments
}

\author{
Kazunori Matsuura $^{1}$, Kenta Watanabe ${ }^{2}$, Yoshihiro Matsushita ${ }^{2}$ and Nobuo Kimizuka ${ }^{2,3}$ \\ The binding behavior of guests (dyes and DNA) into peptide nanocapsules formed via self-assembly of a 24-mer $\beta$-annulus \\ peptide fragment obtained from the capsid protein of the tomato bushy stunt virus is reported. The $\mathrm{pH}$ dependence of \\ the $\zeta$ potential of the peptide nanocapsules indicates that the $\mathrm{C}$ - and $\mathrm{N}$-termini are directed to the exterior and interior \\ of the nanocapsules, respectively. Equilibrium dialysis experiments with dyes and the peptide nanocapsules at pH 7 showed \\ that the peptide nanocapsules tend to bind anionic dyes. Binding of sodium 8-anilinonaphthalene-1-sulfonate and uranine into \\ the peptide nanocapsules minimally affected the size of the nanocapsules, whereas binding of other anionic dyes resulted in \\ the formation of precipitates. In addition, binding of Thioflavin $\mathrm{T}$ to the $\beta$-annulus peptide promoted disassembly of the \\ nanocapsules. Complexation of the $\beta$-annulus peptide with M13 phage DNA formed a core-shell nanosphere in which the \\ DNA was encapsulated in the peptide assembly.
}

Polymer Journal (2013) 45, 529-534; doi:10.1038/pj.2012.235; published online 23 January 2013

Keywords: DNA; guest binding; peptide; self-assembly; spherical virus; $\beta$-annulus

\section{INTRODUCTION}

Natural spherical plant viruses consist of genome nucleic acids encapsulated in an outer protein shell known as the capsid. Viral capsids with icosahedral symmetry have a discrete size, and are formed by self-assembly of capsomere proteins. Recently, because of their fascinating nanostructures with discrete nanospaces, plant viral capsids have attracted much attention as novel materials for nanoreactors and nano-carriers. ${ }^{1-4}$ For example, encapsulation of dyes, ${ }^{5}$ drugs, ${ }^{6}$ proteins, ${ }^{7,8}$ synthetic polymers ${ }^{9,10}$ and inorganic clusters ${ }^{11-13}$ into plant spherical viral capsids has been reported. In addition, Hilvert and coworkers reported that engineered nonviral protein capsids such as lumazine synthase from Aquifex aeolicus are also applicable as nano-carriers for proteins and DNA. ${ }^{14-16}$ Currently, however, functional modification of natural protein capsules, such as plant viral capsids and virus-like lumazine synthase capsids, requires complicated technologies such as gene recombination and protein expression. Therefore, the reconstruction of virus-like nanocapsules from synthetic molecules would enhance their potential for molecular designs. However, the development of chemical strategies for de novo designed virus-like nanocapsules is still in its infancy.

To date, artificial peptide assemblies consisting of coiled-coil $\alpha$-helix ${ }^{17-20}$ and $\beta$-sheet ${ }^{21-24}$ have been reported. We developed virus-inspired $\mathrm{C}_{3^{-}}$and $\mathrm{C}_{5}$-symmetric $\beta$-sheet-forming peptide conjugates $^{25-28}$ and $\mathrm{C}_{3}$-symmetric glutathione conjugates ${ }^{29-31}$ and reported their characteristic self-assembling behavior in water. ${ }^{32}$ Recently, we also synthesized a 24-mer peptide fragment 1
(INHVGGTGGAIMAPVAVTRQLVGS), which participates in the $\beta$-annulus motif in the tomato bushy stunt virus (TBSV) and found that 1 self-assembles in water into virus-like nanocapsules with a diameter of $30-50 \mathrm{~nm} .{ }^{33}$ Herein, we report the binding behavior of guests (dyes and DNA) into the virus-like nanocapsules formed from the $\beta$-annulus peptide (Figure 1).

\section{MATERIALS AND METHODS}

Reagents were obtained from commercial sources and used without further purification. M13 phage DNA (M13 mp18 RF DNA, $7249 \mathrm{bp}$ ) was purchased from TaKaRa Biotechnology Co., Ltd. (Otsu, Japan). Deionized water of high resistivity $(>18 \mathrm{M} \Omega \mathrm{cm})$ purified with a Millipore (Billerica, MA, USA) Purification System (Milli-Q water) was used as the solvent. Synthesis and identification of $\beta$-annulus peptide 1 have been previously described. ${ }^{33}$

\section{Dynamic light scattering (DLS) measurements}

A stock aqueous solution of $\beta$-annulus-24 peptide $1(0.1 \mathrm{~mm}, \mathrm{pH} 4.3)$ was prepared by simply dissolving it in deionized water. Aqueous solutions of the peptide at $\mathrm{pH}$ 2.0, 7.0, 11.1 and 13.0 were prepared by adding a small amount of $10 \mathrm{M} \mathrm{NaOH}$ aq. or $0.1 \mathrm{M} \mathrm{HCl}$ aq. into the stock solution (the $\mathrm{pH}$ of each solution was measured using the Horiba (Kyoto, Japan) twin pH meter B-212). DLS measurements were obtained using a Zetasizer NanoZS (Malvern Instruments Ltd., Worcestershire, UK) instrument at $25^{\circ} \mathrm{C}$ with an incident He-Ne laser $(633 \mathrm{~nm})$. During the measurements, the count rate (the samplescattering intensity) was also provided. The correlation time for the scattered light intensity $G(\tau)$ was measured several times, and the averaged results were fitted to equation 1 , where $B$ is the baseline, $A$ is the amplitude, $q$ is the

\footnotetext{
${ }^{1}$ Department of Chemistry and Biotechnology, Graduate School of Engineering, Tottori University, Tottori, Japan; ${ }^{2}$ Department of Chemistry and Biochemistry, Graduate School of Engineering, Kyushu University, Fukuoka, Japan and ${ }^{3}$ Center for Molecular Systems (CMS), Kyushu University, Fukuoka, Japan

Correspondence: Professor K Matsuura, Department of Chemistry and Biotechnology, Tottori University, Graduate School of Engineering, Koyama-Minami 4-101, Tottori 680-8552, Japan.

E-mail: ma2ra-k@chem.tottori-u.ac.jp

Received 26 November 2012; revised 3 December 2012; accepted 6 December 2012; published online 23 January 2013
} 


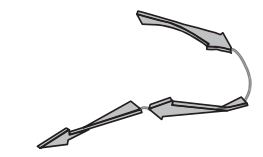

\section{$\beta$-Annulus peptide 1: \\ INHVGGTGGAIMAPVAVTRQLVGS}

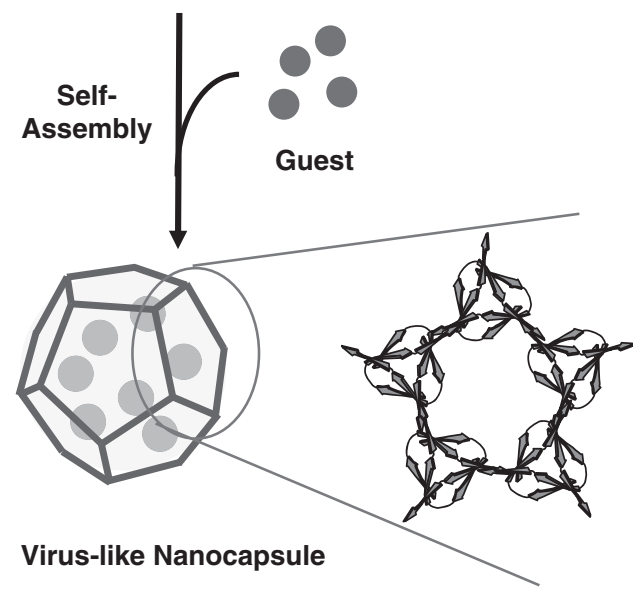

Figure 1 Illustration of the guest binding of virus-like nanocapsules selfassembled from a 24-mer $\beta$-annulus peptide fragment. A full color version of this figure is available at Polymer Journal online.

scattering vector, $\tau$ is the delay time and $D$ is the diffusion coefficient:

$$
G(\tau)=B+A \cdot \exp \left(-2 q^{2} D \tau\right)
$$

The hydrodynamic radius $\left(R_{\mathrm{H}}\right)$ of the scattering particles was calculated using the Stokes-Einstein equation (equation 2), where $\eta$ is the solvent viscosity, $k_{\mathrm{B}}$ is Boltzmann's constant and $T$ denotes the absolute temperature.

$$
R_{\mathrm{H}}=\frac{k_{\mathrm{B}} T}{6 \pi \eta D}
$$

\section{C-Potential measurements}

The $\zeta$ potential of the peptide nanocapsules at $\mathrm{pH} 2.0,4.3,7.0,11.1$, and 13.0 was determined by measuring the electrophoretic mobility in disposable Zeta cells using a Zetasizer NanoZS (Malvern Instruments Ltd.) at $25^{\circ} \mathrm{C}$.

\section{Binding study for dyes}

Aqueous solutions of dyes $(0.1 \mathrm{~mm}, \mathrm{pH} 7)$ were added to powdered samples of peptide 1 and incubated for $60 \mathrm{~min}$ at $25^{\circ} \mathrm{C}$ ([peptide] $=0.1 \mathrm{~mm}$ ). An aliquot $(0.5 \mathrm{ml})$ of each solution was dialyzed to equilibrium against $5 \mathrm{ml}$ of water $(\mathrm{pH}$ 7) at $25^{\circ} \mathrm{C}$ using a Mini Dialysis Kit ( $1 \mathrm{kDa}$ cutoff, GE Healthcare, Tokyo, Japan). The amount of dye permeated through the dialysis membrane was determined from the absorption spectrum (Jasco V-570 spectrophotometer, Jasco, Tokyo, Japan) of the dialyzed bulk solution. The proportion of dye bound to the $\beta$-annulus peptide 1 after dialysis in water was calculated using equation 3

$$
\% \text { of bound dyes }=\left(A_{\text {dye }}-A_{1+\text { dye }}\right) / A_{0} \times 100
$$

where, $A_{0}$ is the absorbance at the $\lambda_{\max }$ of a $0.1 \mathrm{~mm}$ aqueous solution of the dye, and the $A_{\text {dye }}$ is absorbance at the $\lambda_{\max }$ of the dye in the dialyzed bulk solution when the $0.1 \mathrm{~mm}$ dye solution is dialyzed, and $A_{1+\text { dye }}$ is the absorbance when a solution of $0.1 \mathrm{~mm}$ dye and $0.1 \mathrm{~mm}$ peptide 1 assemblies is dialyzed.

Fluorescence spectra of sodium 8-anilinonaphthalene-1-sulfonate (ANS; $0.1 \mathrm{~mm})$ in the absence and presence of peptide 1 were measured at $25^{\circ} \mathrm{C}$ with excitation at $380 \mathrm{~nm}$ using a Perkin Elmer LS-45 instrument (Perkin Elmer, Waltham, MA, USA).
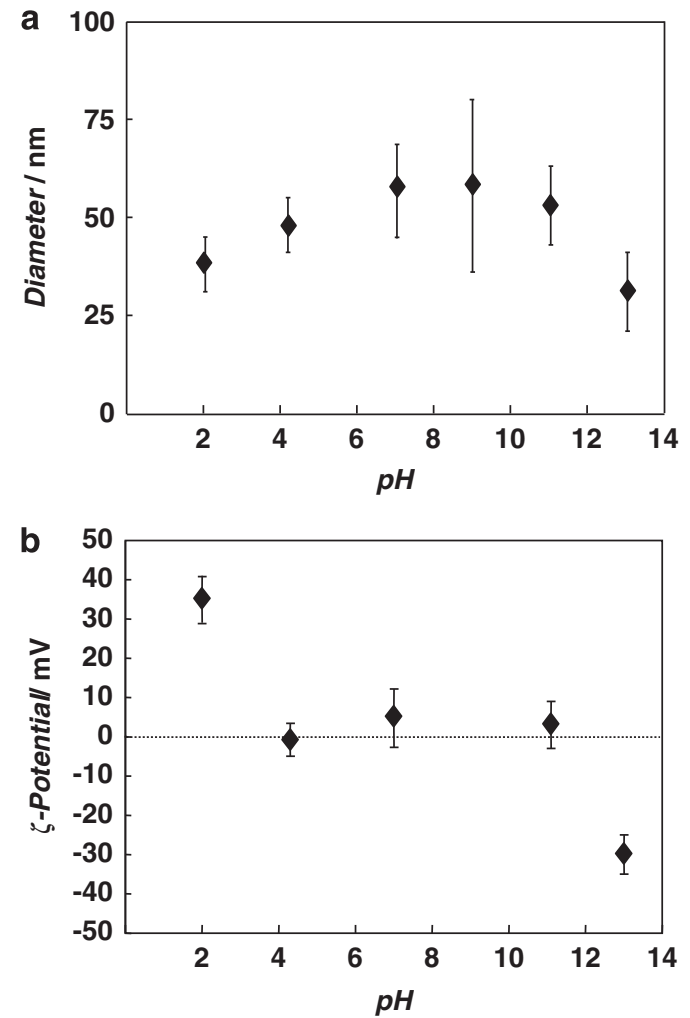

pH $2.0 \quad \stackrel{+}{H}_{3}^{\mathrm{N}-I N H V G G T G G A I M A P V A V T R Q L V G S-C O O H}$

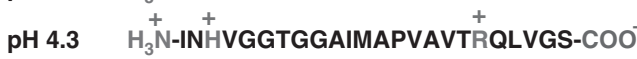

pH 7.0 $\stackrel{+}{H_{3} \mathrm{~N}-I N H V G G T G G A I M A P V A V T R} \stackrel{+}{\mathrm{Q}} \mathrm{QLVGS}-\mathrm{COO}$

pH 11.1 $\mathrm{H}_{2} \mathrm{~N}$-INHVGGTGGAIMAPVAVTR ${ }^{+} \mathrm{QLVGS}^{-C O 0^{-}}$

pH 13.0 $\mathrm{H}_{2} \mathrm{~N}$-INHVGGTGGAIMAPVAVTRQLVGS-COO

Figure 2 Effect of $\mathrm{pH}$ on (a) the size distribution determined by DLS of an aqueous solution of $\beta$-annulus peptide $1(0.1 \mathrm{~mm})$ at $25^{\circ} \mathrm{C}$, (b) the $\zeta$ potentials of the peptide nanocapsules. (c) Expected charges on $\beta$-annulus peptide 1 at various $\mathrm{pH}$. A full color version of this figure is available at Polymer Journal online.

\section{Encapsulation of M13 phage DNA}

An aqueous solution of peptide 1 was gradually added to an aqueous solution of M13 phage DNA and incubated for $60 \mathrm{~min}$ at $25^{\circ} \mathrm{C}$ ([peptide] $=0.050 \mathrm{mM}$ $\left(\left[\right.\right.$ cation $\left.\left.\left._{(\text {peptide })}\right]=0.1 \mathrm{~mm}\right), \quad[\mathrm{DNA}]=13.8 \mathrm{~nm} \quad\left(\left[\operatorname{anion}_{(\mathrm{DNA})}\right]=0.1 \mathrm{~mm}\right)\right) . \quad$ A DLS measurement of the mixture was obtained using a Zetasizer NanoZS (Malvern Instruments Ltd.), as described above.

\section{Transmission electron microscopy (TEM)}

The aqueous solution of M13 phage DNA/peptide 1 ( $10 \mu \mathrm{l})$ was mixed with $10 \mu \mathrm{l}$ of $0.1 \mathrm{~mm}$ aqueous cisplatin (cis-diammine dichloro platinum (II)), and the mixture was applied to a carbon-coated Cu-grid (Oken Co., Ltd., Tokyo, Japan), kept for $60 \mathrm{~s}$, and then removed. The grid was dried in vacuo, and subjected to TEM observation (JEOL JEM-2010, JEOL, Tokyo, Japan) with an acceleration voltage of $100 \mathrm{kV}$. The observed grid was then stained with $10 \mu \mathrm{l}$ of a $2 \mathrm{wt} \%$ aqueous uranyl acetate solution, dried in vacuo, and subjected to TEM observation for second time.

\section{RESULTS AND DISCUSSION}

The $\mathrm{pH}$ dependence of the size distribution obtained from the DLS measurements of the aqueous solution of $\beta$-annulus peptide 1 in 
<smiles>CCOC(=O)c1ccccc1-c1c2cc(C)c(=[N+](CC)CC)cc-2oc2cc(N(CC)CC)c(C)cc12</smiles>

Rhodamine 6G<smiles>CN(C)c1ccc2nc3cc/c(=[N+](\C)Cl)cc-3sc2c1</smiles><smiles>Nc1c(N=Nc2ccc(-c3ccc(N=Nc4cc([S+]([O-])O[NH3+])c5ccccc5c4N)cc3)cc2)cc([O-])c2ccccc12</smiles>
Congo Red

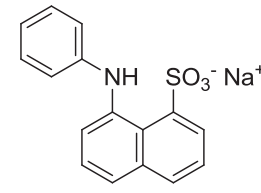

ANS<smiles>CN(C)c1ccc(C(=C2C=CC(=[N+](C)C)C=C2)c2ccc(N(C)C)cc2)cc1</smiles>

Crystal Violet

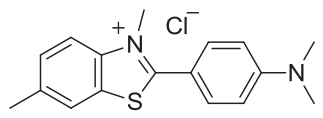

Thioflavine T $\mathrm{Na}^{+}$

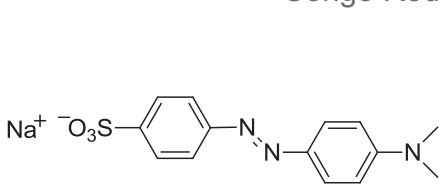

Methyl Orange<smiles>[R5]c1ccccc1-c1c2ccc(=O)c(O)c-2oc2c(O)c(O)ccc12</smiles>

Pyrogallol Red<smiles>O=C(O[N+](=O)[O-])c1ccccc1-c1c2ccc(=O)cc-2oc2cc(O)ccc12</smiles>

Uranine
Chart 1 Structures of the dyes used in this study. A full color version of this figure is available at Polymer Journal online.

water at $25^{\circ} \mathrm{C}$ is shown in Figure $2 \mathrm{a}$. $\beta$-Annulus peptide $\mathbf{1}$ selfassembled into nanocapsules over a wide $\mathrm{pH}$ range, although the sizes of the particles at an acidic and basic $\mathrm{pH}$ were smaller than at a neutral $\mathrm{pH}$. It should be noted that the surface $\zeta$ potentials of the peptide nanocapsules did not match the expected net charges of $\beta$-annulus peptide $\mathbf{1}$ at various $\mathrm{pHs}$ (Figures $2 \mathrm{~b}$ and $\mathrm{c}$ ). The $\zeta$ potentials at $\mathrm{pH} 4.3$ and 7.0 were practically neutral, although the net charges were expected to be +2 and +1 , respectively, while the $\zeta$ potentials at $\mathrm{pH} 2$ and 13 had similar absolute values $(+35 \pm 6$ and $-30 \pm 5 \mathrm{mV}$ ), although the net charges were expected to be +3 and -1 , respectively. These results indicate that the surface $\zeta$ potentials of the peptide nanocapsules are dominated by the charges of the C-terminal sequence (RQLVGS-COOH), and the N-terminal sequence $\left(\mathrm{H}_{2} \mathrm{~N}-\mathrm{INH}\right)$ has a minimal effect. It can also be inferred that the C-terminal is directed to the surface, while the N-terminal is directed to the interior of the peptide nanocapsules, which corresponds to the terminal direction of the natural TBSV capsid. ${ }^{34}$

The binding of dyes (Chart 1) to the peptide nanocapsules was investigated via equilibrium dialysis in water $(\mathrm{pH} 7)$ at $25^{\circ} \mathrm{C}$. These dyes $(0.1 \mathrm{~mm})$ can permeate through the dialysis membrane (cutoff $\mathrm{Mw}=1 \mathrm{kDa}$ ) in the absence of peptide 1 . Aqueous solutions of the

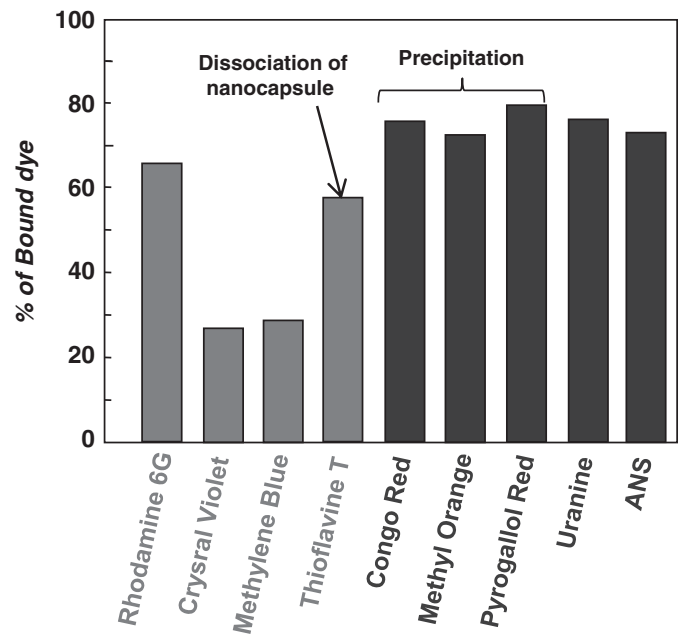

Figure 3 Proportion of dyes bound to $\beta$-annulus peptide 1 after dialysis in water $(\mathrm{pH} \mathrm{7}$, [dyes] $=$ [peptide $\left.]=0.1 \mathrm{~mm}, 25^{\circ} \mathrm{C}\right)$. A full color version of this figure is available at Polymer Journal online.

dyes were added to powdered samples of peptide 1 to encapsulate the dyes within the peptide nanocapsules. The proportion of dye bound to peptide $1(0.1 \mathrm{~mm})$ was quantitatively estimated by measuring the concentration of the dialyzed solution. Notably, the peptide nanocapsules tend to bind anionic dyes rather than cationic dyes (Figure 3). In addition, the binding of ANS and uranine into the peptide nanocapsules minimally affected the size of the nanocapsule (Figure 4), while the binding of other anionic dyes (Congo Red, Methyl Orange and Pyrogallol Red) led to precipitate formation. It is probable that ANS and uranine bind to the cationic interior of the peptide nanocapsule at $\mathrm{pH} 7$ because the N-terminal of peptide 1 would be directed to the interior of the nanocapsules (Figures $2 \mathrm{~b}$ and c). Cationic Rhodamine 6G was also bound to the peptide nanocapsule (Figure 3), but the size of the nanocapsule in the presence of Rhodamine $6 \mathrm{G}$ was larger than that of the peptide nanocapsule alone (Figure 4d). It is presumed that Rhodamine 6G was adsorbed on peptide 1 by hydrophobic interaction, and thus the size of the nanocapsule was affected because of the electrostatic repulsion between the dye and peptide. It is natural to assume the presence of a dynamic equilibrium in these peptide assemblies, which leads to a change in the nanocapsule size upon binding of guest molecules. Interestingly, DLS measurements of an aqueous solution of peptide 1 in the presence of Thioflavin T (ThT), which is known as an amyloidbinding dye, did not afford analyzable autocorrelation data (Supplementary Figure S1), suggesting that ThT promoted the disassembly of the peptide nanocapsules.

Figure 5a shows binding isotherms for ANS and uranine to the peptide nanocapsules $(50 \mathrm{nmol})$ at $25^{\circ} \mathrm{C}$. If these dyes were bound to the nanocapsules through only 1:1 electrostatic interaction, the binding quantity would be saturated at $50 \mathrm{nmol}$. However, these dyes bound to the peptide nanocapsules beyond $50 \mathrm{nmol}$, suggesting that they were physically encapsulated in the interior of the peptide nanocapsules. Although ANS is a polarity-sensitive dye, and its fluorescence spectrum is shifted to a shorter wavelength in a lower polarity environment, the peptide nanocapsule minimally affected the fluorescence spectrum of ANS (Figure 5b). Thus, it seems that ANS is entrapped in the inner aqueous phase of the peptide nanocapsules.

From the $\mathrm{pH}$ dependence of the $\zeta$ potential (Figure 2), it can be expected that the peptide nanocapsules possess a cationic interior and 

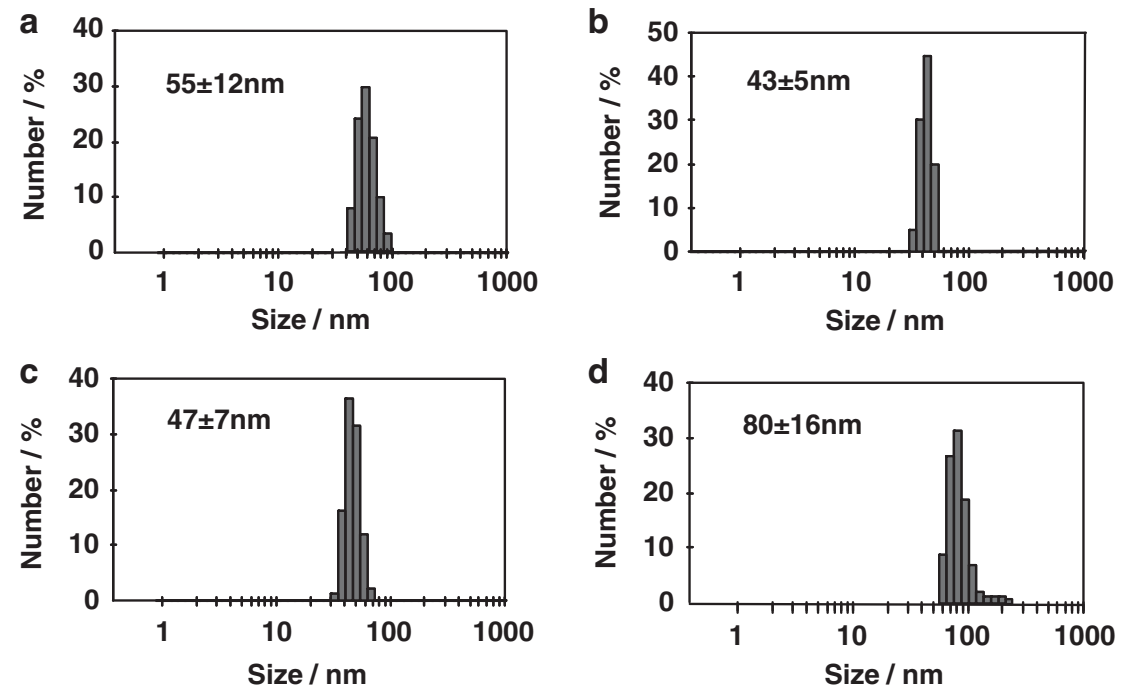

Figure 4 Size distribution obtained from DLS measurements for aqueous solutions of peptide $1(0.1 \mathrm{~mm}$ ) in the absence (a) and presence of ANS (b), uranine (c), and Rhodamine $6 \mathrm{G}(\mathrm{d})(0.1 \mathrm{~mm})$ in water $\left(\mathrm{pH} 7,25^{\circ} \mathrm{C}\right)$. A full color version of this figure is available at Polymer Journal online.

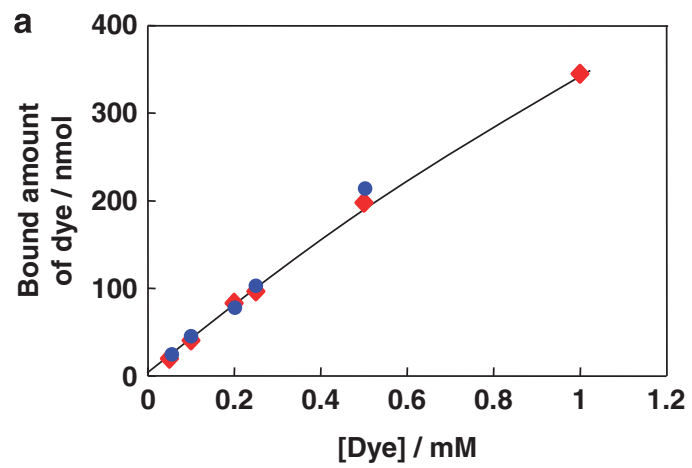

b

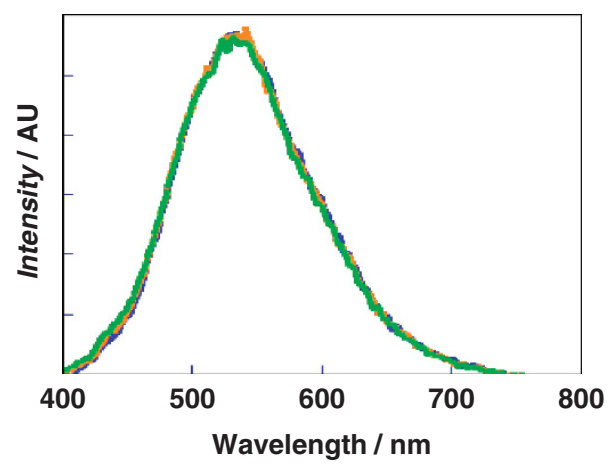

Figure 5 (a) Binding isotherms of ANS (red) and uranine (blue) for the peptide nanocapsules in water $\left(\mathrm{pH} 7,25^{\circ} \mathrm{C}\right)$. (b) Fluorescence spectra of ANS $(0.1 \mathrm{~mm})$ in water $\left(\mathrm{pH} 7,25^{\circ} \mathrm{C}\right), \lambda_{\mathrm{ex}}=380 \mathrm{~nm}$ : ANS alone, green; with $0.1 \mathrm{~mm}$ peptide 1 , blue; with $1.0 \mathrm{mM}$ peptide 1 , orange.

a zwitterionic surface at $\mathrm{pH}$ 4.3. Therefore, we examined the encapsulation of a polyanion, M13 phage DNA (7249 bp) into the peptide nanocapsules under these same conditions. An aqueous solution of peptide 1 was gradually added to an aqueous solution of M13 phage DNA at $\mathrm{pH} 4.3$ to produce equimolar complexes of the cation (peptide) and the anion (DNA). The DNA/peptide 1 complexes did not precipitate, and the average size of the complexes was estimated by DLS to be $82 \pm 17 \mathrm{~nm}$ (Figure 6a). In addition, while the TEM analysis of peptide 1 alone stained with cisplatin did not show any images, TEM observation of the complexes stained with cisplatin, which selectively bind to DNA, showed formation of globular DNA particles with a diameter of $30 \pm 7 \mathrm{~nm}$ (Figures $6 \mathrm{~b}$ and e). In contrast, in the absence of peptide 1, DNA molecules with irregular morphology were observed by TEM (Figure 6d). Furthermore, when uranyl acetate stain was added to the DNA/peptide 1 complexes previously stained with cisplatin, core-shell nanospheres with a diameter of $95 \pm 13 \mathrm{~nm}$ were observed by TEM (Figures $6 \mathrm{c}$ and e). This diameter is comparable to the average value obtained from the DLS measurements (Figure 6a). These results indicate that the M13 phage DNA was compacted and encapsulated in the $\beta$-annulus peptide assemblies to form core-shell spheres, as illustrated in Figure 6f. A possible mechanism for the core-shell particle formation of the DNA/peptide 1 complex is as follows: (1) the cationic peptides are adsorbed onto the DNA via electrostatic interaction and (2) the adsorbed peptides self-assemble into core-shell nanospheres around the compacted DNA. The size of the DNA/peptide 1 complexes $(82 \pm 17 \mathrm{~nm}$ by DLS) was larger than that of the peptide 1 assemblies $(48 \pm 7 \mathrm{~nm}$ by DLS) at $\mathrm{pH}$ 4.5. This dynamic transformation into the core-shell nanospheres is one of the most important features of the present peptide nano-assemblies. This behavior is consistent with the proposed dynamic equilibrium of peptide assemblies that allows them to re-organize upon the binding of guest molecules.

\section{CONCLUSION}

We demonstrated that the $\mathrm{C}$ - and N-termini are directed to the exterior and interior, respectively, of peptide nanocapsules self-assembled from the $\beta$-annulus peptide of TBSV. Relatively small anionic dyes (ANS and uranine) were encapsulated in the nanocapsule, because of the cationic interior environment. A DNA polyanion was also encapsulated in the peptide nanocapsules to form core-shell nanospheres. Modification of the $\beta$-annulus peptide would extend the molecular design of functional nanocapsules that can encapsulate various guest molecules. We 


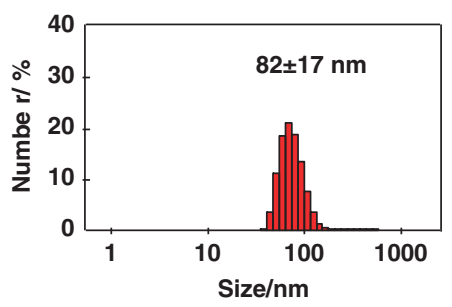

b DNA/1 stained with cisplatin

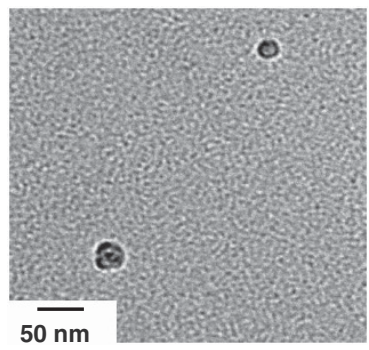

C DNA/1 stained with cisplatin and uranyl acetate

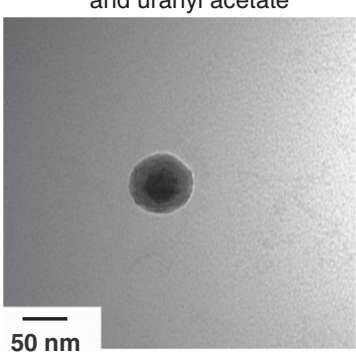

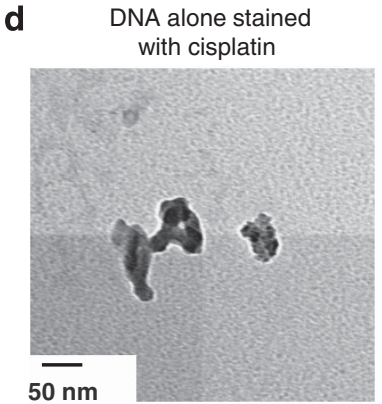

e

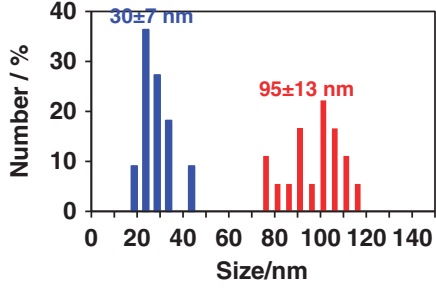

f

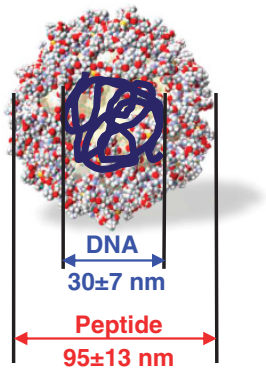

Figure 6 (a) Size distribution obtained from DLS measurements of aqueous solutions of peptide $1(0.050 \mathrm{~mm})$ in the presence of M13 phage DNA (13.8 nM, [anion] $=0.1 \mathrm{~mm})$ in water. (b, c) TEM images of the aqueous solutions used for the DLS measuerements: TEM sample stained with cisplatin (a) and with cisplatin followed by uranyl acetate (b). (d) TEM image of M13 phage DNA alone (13.8nM) stained with cisplatin. (e) Size distribution ( $n=42)$ obtained from the TEM images stained with cisplatin (red) and cisplatin + uranyl acetate (blue). (f) Hypothesized illustration of the DNA-encapsulated peptide nanocapsule.

envisage that the artificial virus-like nanocapsules could be applied to novel nanomaterials for drug and gene delivery systems. ${ }^{35,36}$

\section{ACKNOWLEDGEMENTS}

This research was partially supported by a Grant-in-Aid for Scientific Research on the Innovative Areas of 'Fusion Materials' (No. 2206) from the Ministry of Education, Science, Sports and Culture of Japan (MEXT) and by a Grant-inAid for Scientific Research (B) (No. 22350075) from the Japan Society for the Promotion of Science (JSPS).

1 Douglas, T. \& Young, M. Viruses: making friends with old foes. Science 312, 873-875 (2006).

2 Steinmetz, N. F. \& Evans, D. J. Utilisation of plant viruses in bionanotechnology. Org. Biomol. Chem. 5, 2891-2902 (2007)

3 Bronstein, L. M. Virus-based nanoparticles with inorganic cargo: what does the future hold? Small 7, 1609-1618 (2011).

4 Witus, L. S. \& Francis, M. B. Using synthetically modified proteins to make new materials. Acc. Chem. Res. 44, 774-783 (2011).

5 Loo, L., Guenther, R. H., Lommel, S. A. \& Franzen, S. Infusion of dye molecules into Red clover necrotic mosaic virus. Chem. Commun. 88-90 (2008).

6 Ren, Y., Wong, S. M. \& Lim, L.-Y. Folic acid-conjugated protein cages of a plant virus: a novel deliveryplatform for doxorubicin. Bioconjug. Chem. 18, 836-843 (2007).

7 Comellas-Aragonès, M., Engelkamp, H., Claessen, V. I., Sommerdijik, N. A. J. M., Rowan, A. E., Christianen, P. C. M., Maan, J. C., Verduin, B. J. M., Cornelissen, J. J. L. M. \& Nolte, R. J. M. A virus-based single-enzyme nanoreactor. Nature Nanotech. 2, 635-639 (2007).

8 Minten, I. J., Hendriks, L. J. A., Nolte, R. J. M. \& Cornelissen, J. J. L. M. Controlled encapsulation of multiple proteins in virus capsids. J. Am. Chem. Soc. 131, 1777117773 (2009).

9 Comellas-Aragonès, M., de la Escosura, A., Dirks, A. T. J., van der Ham, A., FustéCuňé, A., Cornelissen, J. J. L. M. \& Nolte, R. J. M. Controlled integration of polymers into viral capsids. Biomacromolecules 10, 3141-3147 (2009).

10 Brasch, M. \& Cornelissen, J. J. L. M. Relative size selection of a conjugated polyelectrolyte in virus-like protein structures. Chem. Commun. 48, 1446-1448 (2012).

11 Douglas, T. \& Young, M. Host-guest encapsulation of materials by assembled virus protein cages. Nature 393, 152-155 (1998).

12 Douglas, T., Strable, E., Willits, D., Aitouchen, A., Libera, M. \& Young, M. Protein engineering of a viral cage for constrained nanomaterials synthesis. Adv. Mater. 14, 415-418 (2002).
13 de la Escosura, A., Verwegen, M., Sikkema, F. D., Comellas-Aragonès, M., Kirilyuk, A., Rasing, T. Nolte, R. J. M. \& Cornelissen, J. J. L. M. Viral capsids as templates for the production of monodisperse Prussian blue nanoparticles. Chem. Commun. 1542-1544 (2008).

14 Seebeck, F. P., Woycechowsky, K. J., Zhuang, W., Rabe, J. P. \& Hilvert, D. A simple tagging system for protein encapsulation. J. Am. Chem. Soc. 128, 45164517 (2006).

15 Wörsdörfer, B., Pianowski, Z. \& Hilvert, D. Efficient in vitro encapsulation of protein cargo by an engineered protein container. J. Am. Chem. Soc. 134, 909-911 (2012).

16 Lilavivat, S., Sardar, D., Jana, S., Thomas, G. C. \& Woycechowsky, K. J. In vivo encapsulation of nucleic acids using an engineered nonviral protein capsid. J. Am. Chem. Soc. 134, 13152-13155 (2012).

17 Ryadnov, M. G. \& Woolfson, D. N. Engineering the morphology of a self-assembling protein fibre. Nat. Mater. 2, 329-332 (2003).

18 Ryadnov, M. G. \& Woolfson, D. N. Introducing branches into a self-assembling peptide fiber. Angew. Chem. Int. Ed. 42, 3021-3023 (2003).

19 Zhou, M., Bentley, D. \& Ghosh, I. Helical supramolecules and fibers utilizing leucine zipper-displaying dendrimers. J. Am. Chem. Soc. 126, 734-735 (2004).

20 Boyle, A. L., Bromley, E. H. C., Bartlett, G. J., Sessions, R. B., Sharp, T. H., Williams, C. L., Curmi, P. M. G., Forde, N. R., Linke, H. \& Woolfson, D. N. Squaring the circle in peptide assembly: from fibers to discrete nanostructures by de novo design. J. Am. Chem. Soc. 134, 15457-15467 (2012).

21 Marini, D. M., Hwang, W., Lauffenburger, D. A., Zhang, S. \& Kamm, R. D. Left-handed helical rbbon intermediates in the self-assembly of a $\beta$-sheet peptide. Nano Lett. 2, 295-299 (2002).

22 Yokoi, H., Kinoshita, T. \& Zhang, S. Dynamic reassembly of peptide RADA16 nanofiber scaffold. Proc. Natl Acad. Sci. USA 102, 8414-8419 (2005).

23 Takahashi, T. \& Mihara, H. Peptide and protein mimetics inhibiting amyloid $\beta$-peptide aggregation. Acc. Chem. Res. 41, 1309-1318 (2008).

24 Sawada, T., Takahashi, T. \& Mihara, H. Affinity-based screening of peptides recognizing assembly states of self-assembling peptide nanomaterials. J. Am. Chem. Soc. 131, 14434-14441 (2009).

25 Matsuura, K., Murasato, K. \& Kimizuka, N. Artificial peptide-nanospheres selfassembled from three-way junctions of $\beta$-sheet-forming peptides. J. Am. Chem. Soc. 127, 10148-10149 (2005).

26 Murasato, K., Matsuura, K. \& Kimizuka, N. Self-assembly of nanofiber with uniform width from wheel-type trigonal- $\beta$-sheet forming peptide. Biomacromolecules 9, 913918 (2008)

27 Matsuura, K., Hayashi, H., Murasato, K. \& Kimizuka, N. Trigonal tryptophane-zipper as a novel building block for $\mathrm{pH}$-responding peptide nano-assemblies. Chem. Commun. 47, 265-267 (2011). 
28 Matsuura, K., Murasato, K. \& Kimizuka, N. Syntheses and self-assembling behaviors of pentagonal conjugates of tryptophane zipper-forming peptide. Int. J. Mol. Sci. 12, 5187-5199 (2011).

29 Matsuura, K., Matsuyama, H., Fukuda, T., Teramoto, T., Watanabe, K., Murasato, K. \& Kimizuka, N. Spontaneous self-assembly of nano-spheres from trigonal conjugate of glutathione in water. Soft Matter 5, 2463-2470 (2009).

30 Matsuura, K., Fujino, K., Teramoto, T., Murasato, K. \& Kimizuka, N. Glutathione nanospheres: self-assembly of conformation-regulated trigonal-glutathiones in water. Bull. Chem. Soc. Jpn 83, 880-886 (2010).

31 Matsuura, K., Tochio, K., Watanabe, K. \& Kimizuka, N. Controlled release of guest molecules from spherical assembly of trigonal gultathione by disulfide recombination. Chem. Lett. 40, 711-713 (2011).
32 Matsuura, K. Construction of spherical virus-inspired peptide nanoassemblies. Polym. J. 44, 469-474 (2012).

33 Matsuura, K., Watanabe, K. Sakurai, K. Matsuzaki, T. \& Kimizuka, N. Self-assembled synthetic viral capsids from a 24-mer viral peptide fragment. Angew. Chem. Int. Ed. 49, 9662-9665 (2010)

34 Olson, J., Bricogne, G. \& Harrison, S. C. Structure of Tomato Bushy Stunt Virus IV. The virus particle at $2.9 \AA$ resolution. J. Mol. Biol. 171, 61-93 (1983).

35 Lamarre, B. \& Ryadnov, M. G. Self-assembling viral mimetics: one long journey with short steps. Macromol. Biosci. 11, 503-513 (2011).

36 Miyata, K., Nishiyama, N. \& Kataoka, K. Rational design of smart supramolecular assemblies for gene delivery: chemical challenges in the creation of artificial viruses. Chem. Soc. Rev. 41, 2562-2574 (2012).

Supplementary Information accompanies the paper on Polymer Journal website (http://www.nature.com/pj) 